\title{
Fisheries Resources in the Deep Waters of the Eastern Mediterranean (Greek Ionian Sea)
}

\author{
C.-Y. Politou, S. Kavadas and Ch. Mytilineou \\ National Centre for Marine Research, Ag. Kosmas, 16604 Helliniko, Athens, Greece \\ A. Tursi and R. Carlucci \\ Department of Zoology, University of Bari, Via Orabona 4, I-70125 Bari, Italy \\ G. Lembo \\ COISPA, Tecnologia e Ricerca, Mola di Bari, C.P. 62, Italy
}

\begin{abstract}
The deep waters of the Greek seas are unexploited, since trawling is carried out mainly down to $400 \mathrm{~m}$. In the present work, the fisheries resources of the deep waters (300-900 m) of the Greek Ionian Sea were studied in spring, summer and autumn 2000 by means of experimental trawl surveys. The results showed that in the zone $300-500 \mathrm{~m}$, fish composed $73-83 \%$ by number or $89-92 \%$ by weight of the catch depending on the season, crustaceans $16-25 \%$ by number or $6 \%$ by weight and cephalopods $1-2 \%$ by number or $3-5 \%$ by weight. In the zone $500-700 \mathrm{~m}$, crustaceans composed $28-41 \%$ by numbers or $67-80 \%$ by weight of the catch, whereas the proportion of cephalopods was less than $1 \%$ by number and about $1 \%$ by weight. In the deepest zone ( $700-$ $900 \mathrm{~m}$ ), the proportion of cephalopods remained negligible, whereas the proportion of fish increased and was about equal in numbers with that of crustaceans, whereas in weight it ranged from 81 to $86 \%$. The CPUE of commercial fish was $23-59 \mathrm{~kg} / \mathrm{hr}$ in the first depth stratum, 7-25 $\mathrm{kg} / \mathrm{hr}$ in the second one and $2-10 \mathrm{~kg} / \mathrm{hr}$ in the third one, depending on the season. Concerning the commercial crustaceans, their CPUE was $3-6.5 \mathrm{~kg} / \mathrm{hr}$ in the shallowest zone, $6-8.5 \mathrm{~kg} / \mathrm{hr}$ in the middle one and $2-4 \mathrm{~kg} / \mathrm{hr}$ in the deepest one. The commercial part of cephalopod catch ranged from 1 to $7 \mathrm{~kg} / \mathrm{hr}$ in the zone $300-500 \mathrm{~m}$, whereas deeper it was negligible. Commercial/total ratio by weight of the whole catch was highest in the 500-700 $\mathrm{m}$ zone $(0.60-0.78)$, whereas in the other zones it was generally lower than 0.50 .
\end{abstract}

Key words: fisheries resources, deep water, Mediterranean Sea, seasonality

\section{Introduction}

The overexploitation of the continental shelves in most of the world has led to an increasing interest in deep-water fisheries. Deep-water trawl fisheries and generally large-scale modern fisheries based on deepsea species began in the 1970s in different areas of the world such as in the west of Scotland and Ireland and in Australia and New Zealand (Gordon, 2001; Haedrich et al., 2001).

In the Mediterranean, deep waters are exploited by trawl in its western and central part. Trawl fishing, targeting mainly red shrimps, is carried out in Mediterranean Spanish waters and Italian waters down to 800-1 $000 \mathrm{~m}$ of depth (Sardà and Cartes, 1994; Carbonell, 1994; Righini and Abella, 1994). In parallel, knowledge on the deep-water fisheries resources of this part of the Mediterranean comes from scientific research, which has recently been expanded also to depths greater than $800-1000 \mathrm{~m}$ (e.g. Abella et al., 1988; Cartes and Sardà, 1992, 1993; Cartes, 1993; Cartes et al., 1994; D'Onghia et al., 1998; Stefanescu et al., 1992a, b, 1993, 1994; Ungaro et al., 1999).

In the Greek waters, the commercial fishery is carried out mainly down to a depth of $400 \mathrm{~m}$. The geomorphology of the Greek continental margin, and particularly that of the Ionian Sea, is characterized by steep bottoms and narrow continental shelf. As a result, large marine grounds remain unexploited, while the stocks of a narrow area along the coast suffer from overexploitation (Stergiou et al., 1997).

With little or no deep water fishing in the Greek seas, scientists have been given the opportunity to study the natural environment in order to determine the distribution and abundance of local populations, study their biology and dynamics and plan a reasonable management design. This kind of research started recently in the framework of larger projects (MEDITS 
projects 1994-2001) or in restricted areas of the Ionian Sea (Anon., 1999; Anon., 2001) and Cretan Sea (Kallianiotis et al., 2000). The present study is carried out in an extended area of the Ionian Sea in the framework of the project INTERREG Italy-Greece. In this paper, the results concerning the fisheries resources of the deep waters of the Greek Ionian Sea for different depth strata and seasons are presented.

\section{Materials and Methods}

Sampling took place at depths from 300 to $900 \mathrm{~m}$ in the Greek Ionian Sea during spring, summer and autumn 2000 (Fig. 1) using a chartered commercial trawler. The size of the fishing vessel was $33.1 \mathrm{~m}$ maximum length and $8 \mathrm{~m}$ maximum width, and its engine power was $730 \mathrm{HP}$. The gear used was an Italian type bottom trawl with a cod end mesh size of 20 $\mathrm{mm}$ (side). The horizontal and vertical opening of the trawl were estimated, using a remote acoustic sensing system attached to the gear, as $1.5 \mathrm{~m}$ and $17 \mathrm{~m}$ respectively at a towing speed of 2.4 knots. The random stratified sampling design was applied using depth for the stratification of the study area. Three depth zones were defined, $300-500 \mathrm{~m}, 500-700 \mathrm{~m}$ and $700-900 \mathrm{~m}$. A total of 107 hauls were carried out (Table 1). The tow duration was 30 minutes for depths $<500 \mathrm{~m}$ and one hour for depths $>500 \mathrm{~m}$. After each haul, catches were identified to species level. Species abundance in number and weight were recorded on board. The catch per unit effort (CPUE) in weight per fishing hour was estimated as follows for each depth zone:

$$
\mathrm{CPUE}=\sum W_{n} / \sum t_{n}
$$

where $\Sigma W_{n}=$ sum of weights of a species or category in the $\mathrm{n}$ hauls carried out in the depth zone and $\Sigma t_{n}=$ sum of fishing time of the $n$ hauls in the depth zone. The Mann-Whitney non parametric test was used to check if there were statistically significant differences in CPUE in relation to depth or to season $(p<0.05)$. Consequently, the commercial/total $(\mathrm{C} / \mathrm{T})$ ratio was calculated for each fishing category and for the total catch. The separation between commercial and noncommercial species is shown in Table 2 .

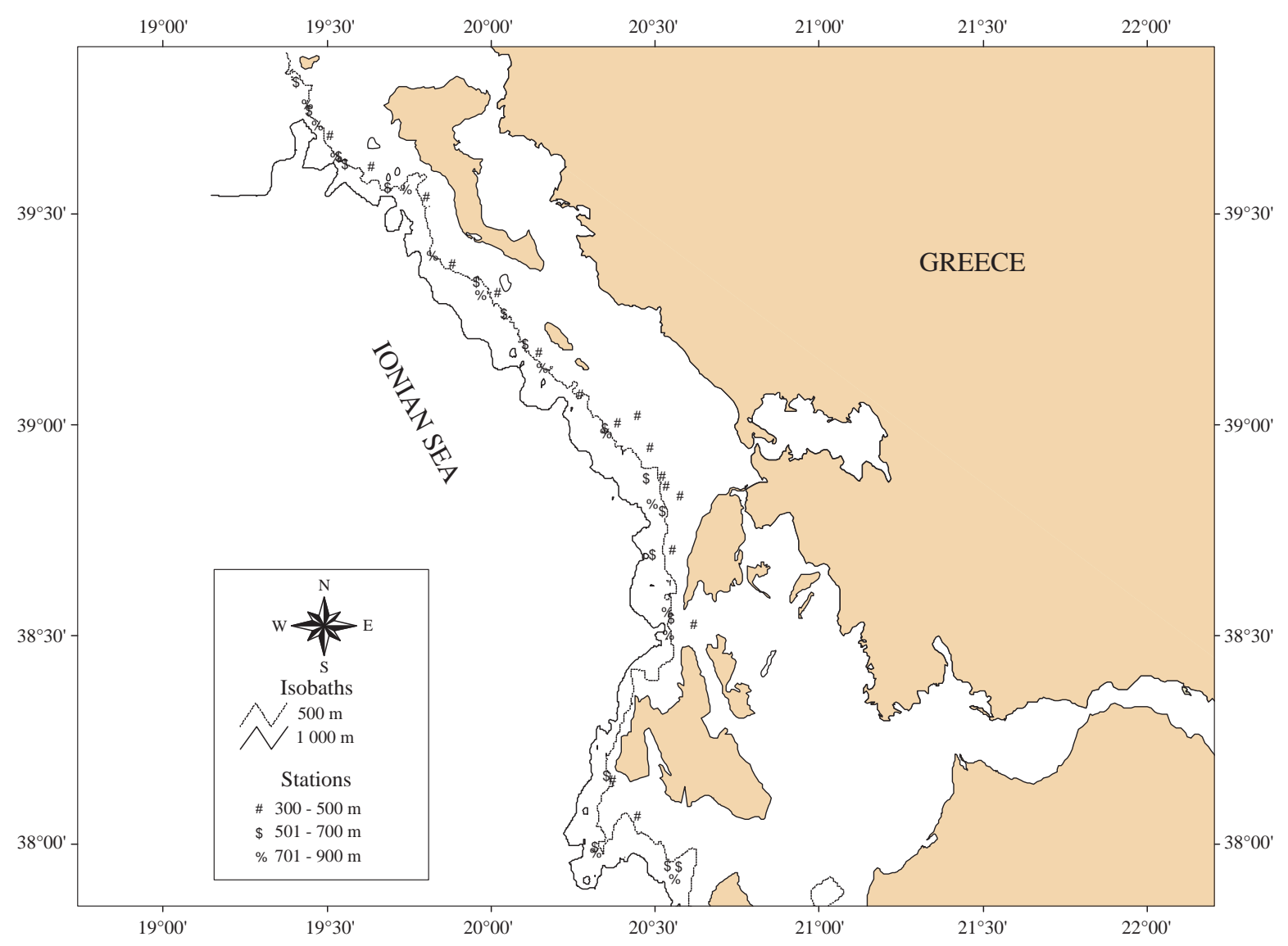

Fig. 1. Map of the study area showing the sampling stations. 
TABLE 1. Number of hauls carried out in the Ionian Sea per season and depth stratum.

\begin{tabular}{lrcc}
\hline \hline & \multicolumn{3}{c}{ Season/depth stratum } \\
\cline { 2 - 4 } & $300-500 \mathrm{~m}$ & $500-700 \mathrm{~m}$ & $700-900 \mathrm{~m}$ \\
\hline Spring & 17 & 17 & 13 \\
Summer & 6 & 15 & 11 \\
Autumn & 3 & 14 & 11 \\
\hline
\end{tabular}

TABLE 2. List of species caught with CPUE ( $\mathrm{kg} / \mathrm{hr})$ per depth stratum and season. In bold are shown the commercial or possibly commercial species.

\begin{tabular}{|c|c|c|c|c|c|c|c|c|c|}
\hline Species & \multicolumn{3}{|c|}{$300-500 \mathrm{~m}$} & \multicolumn{3}{|c|}{$500-700 \mathrm{~m}$} & \multirow[t]{2}{*}{ Spring } & \multicolumn{2}{|c|}{$\begin{array}{l}\text { 700-900 m } \\
\text { Summer Autumn }\end{array}$} \\
\hline & & & FISH & & & & & & \\
\hline Argentina sphyraena & 2.99 & 5.83 & 2.55 & 0.01 & 0.04 & 0.03 & & & 0.04 \\
\hline Arnoglossus rueppelli & 0.15 & 0.10 & 0.01 & & & & & & \\
\hline Aspitrigla cuculus & 0.32 & 0.28 & & & & & & & \\
\hline Capros aper & 0.60 & 4.25 & 0.11 & & & & & & \\
\hline Centracanthus cirrus & 0.03 & & & & & & & & \\
\hline Centrolophus niger & & & & & & 0.41 & & & 0.78 \\
\hline Centrophorus granulosus & & & & 0.19 & & 2.34 & 0.41 & 0.73 & \\
\hline Chauliodus sloani & & 0.03 & & 0.01 & 0.01 & & 0.01 & 0.03 & 0.01 \\
\hline Chimaera monstrosa & & & & 0.07 & & & 0.15 & 0.11 & \\
\hline Chlorophthalmus agassizii & 25.50 & 42.28 & 47.70 & 1.55 & 3.91 & 1.14 & & 0.04 & 0.25 \\
\hline Coelorhynchus coelorhynchus & 0.96 & 1.47 & 1.16 & 0.08 & 0.24 & 0.16 & & 0.01 & 0.03 \\
\hline Conger conger & 0.11 & 0.10 & 0.45 & 0.21 & & 0.09 & 0.43 & 0.02 & 0.43 \\
\hline Dalatias licha & & & & 0.04 & 0.02 & & 0.62 & 1.04 & 0.49 \\
\hline Deltentosteus quadrimaculatus & & 0.01 & & & & & & & \\
\hline Diaphus metopoclampus & & & & & & 0.01 & & & \\
\hline Epigonus constanciae & & & & & 0.02 & & & & \\
\hline Epigonus telescopus & 0.05 & & & & 0.04 & & & 0.17 & \\
\hline Etmopterus spinax & 0.02 & & & 0.11 & 0.30 & 0.12 & 0.12 & 0.26 & 0.34 \\
\hline Eutrigla gurnardus & & & 0.03 & & & & & & \\
\hline Gadella maraldi & & & & & & & 0.02 & & \\
\hline Gadiculus argenteus argenteus & 1.11 & 4.53 & 12.41 & & & & & & \\
\hline Galeus melastomus & 1.42 & 3.46 & 4.14 & 2.93 & 5.69 & 4.16 & 4.37 & 8.67 & 4.62 \\
\hline Gnathophis mystax & & & & & & & 0.03 & & \\
\hline Helicolenus dactylopterus & 2.06 & 1.03 & 0.38 & 4.13 & 7.90 & 7.13 & 1.39 & 2.54 & 1.79 \\
\hline Heptranchias perlo & & 0.53 & & & & & & & \\
\hline Hexanchus griseus & & & & & & & & & 1.33 \\
\hline Hoplostethus mediterraneus & & 0.13 & & 1.00 & 3.74 & 1.84 & 0.75 & 1.81 & 0.87 \\
\hline Hymenocephalus italicus & 0.55 & 3.41 & 2.00 & 0.19 & 0.34 & 0.21 & 0.01 & 0.02 & 0.03 \\
\hline Lampanyctus crocodilus & & 0.03 & & 0.11 & 0.19 & 0.08 & 0.17 & 0.29 & 0.17 \\
\hline Lepidopus caudatus & 0.01 & 0.22 & & 0.04 & 0.02 & 0.12 & & & \\
\hline Lepidorhombus boscii & 2.04 & 3.40 & 6.75 & 0.13 & 1.01 & 1.20 & & & 0.11 \\
\hline Lepidorhombus whiffiagonis & 1.24 & 0.79 & 0.75 & & 0.27 & 0.65 & & & 0.11 \\
\hline Lepidotrigla dieuzeidei & 0.81 & 0.82 & 0.19 & & 0.01 & & & & \\
\hline Lophius budegassa & 1.16 & 2.23 & 1.24 & 0.42 & 0.48 & 0.24 & & 1.82 & 0.02 \\
\hline Lophius piscatorius & 2.19 & & & & 3.36 & 3.60 & & 4.32 & \\
\hline Maurolicus muelleri & & 0.04 & & & & & & & \\
\hline Merluccius merluccius & 1.45 & 6.21 & 9.23 & 0.18 & 0.53 & 2.02 & 0.03 & 0.10 & 0.43 \\
\hline Micromesistius poutassou poutassou & 0.39 & 1.44 & 17.29 & 0.18 & 0.18 & 0.33 & & & \\
\hline Molva dipterygia macrophthalma & 0.08 & 0.23 & & 0.04 & 0.26 & 0.11 & & 0.10 & 0.04 \\
\hline
\end{tabular}


TABLE 2. (Continued). List of species caught with CPUE ( $\mathrm{kg} / \mathrm{hr})$ per depth stratum and season. In bold are shown the commercial or possibly commercial species.

\begin{tabular}{|c|c|c|c|c|c|c|c|c|c|}
\hline Species & \multicolumn{3}{|c|}{$300-500 \mathrm{~m}$} & \multicolumn{3}{|c|}{$500-700 \mathrm{~m}$} & \multicolumn{3}{|c|}{$700-900 \mathrm{~m}$} \\
\hline \multicolumn{10}{|c|}{ FISH (Continued) } \\
\hline Mora moro & & & & 0.03 & 0.09 & 0.10 & 1.75 & 2.96 & 1.44 \\
\hline Mullus barbatus & 0.01 & & & & & & & & \\
\hline Mullus surmuletus & 0.60 & & & & & & & & \\
\hline Mustelus mustelus & & & & & 0.80 & & & & \\
\hline Nettastoma melanurum & 0.02 & 0.08 & 0.13 & 0.11 & 0.27 & 0.12 & 0.41 & 0.59 & 0.42 \\
\hline Nezumia sclerorhynchus & & 0.03 & & 0.28 & 0.50 & 0.54 & 0.38 & 0.58 & 0.37 \\
\hline Notacanthus bonapartei & & & & & & & 0.01 & & \\
\hline Oxynotus centrina & & & & & & 0.38 & & 0.01 & 0.03 \\
\hline Pagellus acarne & 0.47 & 0.05 & & & & & & & \\
\hline Pagellus bogaraveo & 0.55 & 1.42 & 3.75 & 0.34 & 0.56 & 0.11 & & & 0.15 \\
\hline Peristedion cataphractum & 1.79 & 3.28 & 0.90 & 0.13 & 0.07 & 0.07 & 0.01 & & 0.03 \\
\hline Phycis blennoides & 0.91 & 1.68 & 2.19 & 0.63 & 1.38 & 2.23 & 0.14 & 0.99 & 0.50 \\
\hline Polyprion americanus & & & & & & 0.28 & 0.16 & & \\
\hline Raja asterias & & 0.14 & 0.32 & & & & & & \\
\hline Raja clavata & 1.26 & 0.50 & 1.47 & & & & & & \\
\hline Raja miraletus & & & 0.75 & & & & & & \\
\hline Raja montagui & 0.15 & 0.55 & & & & & & & \\
\hline Raja oxyrinchus & 3.01 & 2.11 & 0.60 & 0.03 & 0.16 & 0.21 & & & \\
\hline Raja polystigma & 0.03 & & & & & & & & \\
\hline Scorpaena elongata & 0.55 & 0.38 & & 0.04 & & & & & \\
\hline Scyliorhinus canicula & 1.33 & 1.78 & 6.02 & 0.03 & & & 0.01 & & 0.03 \\
\hline Spicara smaris & 0.01 & & & & & & & & \\
\hline Squalus blainvillei & 6.70 & 3.02 & 10.28 & 0.04 & 0.13 & 4.97 & 0.01 & 0.56 & 0.29 \\
\hline Stomias boa & & 0.01 & & 0.01 & 0.04 & 0.01 & & 0.03 & 0.01 \\
\hline Synchiropus phaeton & 0.02 & 0.03 & & & 0.01 & & & & \\
\hline Torpedo marmorata & 0.03 & & & & & & & & \\
\hline Torpedo nobiliana & 0.37 & & & & & & & & \\
\hline Trachurus picturatus & 0.13 & & & & & & & & \\
\hline Trachurus trachurus & 0.24 & 0.18 & & & & & & & \\
\hline Trachyrhynchus trachyrhynchus & 0.02 & & & & & & 0.16 & 0.17 & 0.17 \\
\hline Trigla lucerna & & 0.22 & & & & & & & \\
\hline Trigla lyra & 0.66 & 0.30 & 0.30 & 0.02 & 0.01 & 0.07 & & & \\
\hline Trisopterus minutus capelanus & & 0.02 & & & & & & & \\
\hline Zeus faber & 0.02 & & & & & & & & \\
\hline
\end{tabular}

\section{CRUSTACEANS}

Aegaeon lacazei

Aristaeomorpha foliacea

Aristeus antennatus

Bathynectes longipes

Bathynectes maravigna

Calappa granulata

Chlorotocus gracicornis

Geryon longipes

Macropipus tuberculatus

Munida iris

Munida perarmata

Nephrops norvegicus

Parapenaeus longirostris

Paromola cuvieri
0.01

0.01

0.01

0.04

0.01

$\begin{array}{llllll}4.29 & 5.71 & 5.84 & 1.79 & 2.81 & 1.23 \\ 0.53 & 0.65 & 0.39 & 0.74 & 1.07 & 0.29 \\ & & 0.01 & & & \end{array}$

0.01

0.01
$0.07 \quad 0.01$

$\begin{array}{ll}0.19 & 0.40\end{array}$

$2.44 \quad 4.69$
0.41

0.17

0.03
0.21

0.18

0.05
0.07

0.07

0.02
$0.01 \quad 0.05$

$0.01 \quad 0.01$

$0.03 \quad 0.04$ 
TABLE 2. (Continued). List of species caught with CPUE ( $\mathrm{kg} / \mathrm{hr})$ per depth stratum and season. In bold are shown the commercial or possibly commercial species.

\begin{tabular}{|c|c|c|c|c|c|c|c|c|c|}
\hline \multirow[b]{2}{*}{ Species } & \multicolumn{3}{|c|}{$300-500 \mathrm{~m}$} & \multicolumn{3}{|c|}{$500-700 \mathrm{~m}$} & \multicolumn{3}{|c|}{$700-900 \mathrm{~m}$} \\
\hline & Spring & Summer & Autumn & Spring & Summer & Autumn & Spring & Summer & Autumn \\
\hline \multicolumn{10}{|c|}{ CRUSTACEANS (Continued) } \\
\hline Parthenope macrochelos & 0.01 & & & & & & & & \\
\hline Pasiphaea multidentata & & & & & & & & 0.01 & 0.01 \\
\hline Pasiphaea sivado & & & & 0.01 & 0.25 & 0.01 & & & \\
\hline Plesionika acanthonotus & 0.01 & & & 0.04 & 0.01 & 0.01 & & & \\
\hline Plesionika antigai & 0.16 & 0.10 & 0.04 & & 0.01 & & & & \\
\hline Plesionika edwardsii & 0.52 & 0.07 & & 0.04 & 0.05 & 0.07 & & & 0.83 \\
\hline Plesionika gigliolii & 0.03 & 0.08 & 0.04 & 0.02 & 0.01 & & & & \\
\hline Plesionika heterocarpus & 0.30 & 0.97 & 2.81 & & 0.01 & & & & \\
\hline Plesionika martia & 0.12 & & & 1.32 & 1.79 & 1.57 & 0.01 & 0.04 & 0.02 \\
\hline Polycheles typhlops & & & & 0.06 & 0.06 & 0.07 & 0.04 & 0.04 & 0.03 \\
\hline Sergestes robustus & & & & & & & 0.01 & 0.01 & 0.01 \\
\hline
\end{tabular}

\section{CEPHALOPODS}

Alloteuthis media

Ancistroteuthis lichtensteini

Eledone cirrhosa

Illex coindetii

Loligo forbesi

Neorossia caroli

Octopus salutii

Octopus vulgaris

Pteroctopus tetracirrhus

Rondeletiola minor

Rossia macrosoma

Scaeurgus unicirrhus

Sepia elegans

Sepia orbignyana

Sepietta oweniana

Sepiola ligulata

Todarodes sagittatus

Todaropsis eblanae

$\begin{array}{lll} & 0.01 & 0.01 \\ 0.01 & 0.01 & \\ \mathbf{0 . 0 1} & \mathbf{0 . 0 2} & \mathbf{0 . 1 0} \\ \mathbf{0 . 1 3} & & \mathbf{1 . 1 3} \\ \mathbf{0 . 5 1} & \mathbf{1 . 5 7} & \mathbf{2 . 0 5} \\ & & \\ 0.01 & & 0.03 \\ & & \\ 0.47 & 0.85 & 0.01 \\ 0.02 & 0.03 & 0.03 \\ 0.05 & 0.11 & 0.24 \\ 0.04 & 0.02 & 0.03 \\ 0.03 & 0.07 & \\ \mathbf{0 . 0 9} & \mathbf{0 . 0 5} & \mathbf{0 . 0 5} \\ 0.13 & 0.21 & 0.51 \\ & 0.02 & \\ & \mathbf{0 . 5 8} & \mathbf{3 . 3 0} \\ \mathbf{0 . 4 9} & \mathbf{0 . 0 5} & \mathbf{0 . 2 1}\end{array}$

$\begin{array}{llll} & \mathbf{0 . 0 6} & \mathbf{0 . 1 2} & \\ 0.05 & 0.05 & 0.04 & 0.02\end{array}$

0.03

$0.02 \quad 0.04$

0.02

0.03

$0.16 \quad 0.34$

$0.05 \quad 0.02$

\section{Results}

\section{Catch composition}

Fish was the main component of the catch by weight independently of depth and season, whereas in terms of numbers, fish dominated in the catch only in the first stratum (Fig. 2). Crustaceans ranked second, after fish, in weight in all cases. However, in terms of numbers crustaceans were dominant in the 500-700 m depth zone during all seasons and almost equal to fish in the deepest zone. Finally, cephalopods always composed a low proportion of the catch (0.1$5.1 \%$ by weight and $0.2-2 \%$ by number) being more important in the first stratum $(300-500 \mathrm{~m})$.
A list of species of each category caught per depth stratum and season is given in Table 2 .

\section{CPUE}

The total CPUE ranged from $14 \mathrm{~kg} / \mathrm{hr}$ to $150 \mathrm{~kg} / \mathrm{hr}$ depending on the depth stratum and the season (Table 3). CPUE varied with depth, during all seasons, it was highest in the first stratum $(300-500 \mathrm{~m})$, and it decreased gradually reaching its minimum in the deepest stratum (700-900 m). With respect to seasonality CPUE was lowest at all depths during spring, although in the deepest stratum, the seasonal difference was not statistically significant (Table 3). A similar bathymetric and seasonal pattern was followed by the 
TABLE 3. CPUE (Kg/hr) of the total, commercial (CO) and non-commercial (NC) catch per depth zone and season. The ratio of the commercial to the total catch $(\mathrm{C} / \mathrm{T})$ is also presented. (In parentheses is given the standard deviation. ${ }^{1, \ldots, 7}$ indicate homogenous groups for the total catch, ${ }^{\mathrm{a}, \ldots, \mathrm{e}}$ indicate homogenous groups for the commercial catch and $\mathrm{I}, . ., \mathrm{VIII}$ indicate homogenous groups for the non-commercial catch, Mann-Whitney test, $P<0.05)$.

\begin{tabular}{|c|c|c|c|c|}
\hline \multirow[b]{2}{*}{ Season } & & \multicolumn{3}{|c|}{ Depth zone } \\
\hline & & $300-500 \mathrm{~m}$ & $500-700 \mathrm{~m}$ & $700-900 \mathrm{~m}$ \\
\hline \multirow{7}{*}{ Spring } & \multirow[t]{2}{*}{$\mathrm{CO}$} & $27.28^{\mathrm{b}}$ & 12.99 & $4.98^{\mathrm{e}}$ \\
\hline & & (16.87) & $(7.08)$ & $(4.41)$ \\
\hline & \multirow[t]{2}{*}{$\mathrm{NC}$} & $42.70^{\mathrm{IV}, \mathrm{V}}$ & $7.08^{\mathrm{I}, \mathrm{VI}}$ & $9.25^{\mathrm{I}, \mathrm{VIII}}$ \\
\hline & & $(35.74)$ & $(6.72)$ & $(5.86)$ \\
\hline & \multirow[t]{2}{*}{ Total } & $69.98^{4}$ & $20.07^{1}$ & $14.23^{1,7}$ \\
\hline & & $(42.40)$ & (10.14) & $(9.39)$ \\
\hline & $\mathrm{C} / \mathrm{T}$ & 0.39 & 0.65 & 0.35 \\
\hline \multirow{7}{*}{ Summer } & \multirow[t]{2}{*}{$\mathrm{CO}$} & $31.87^{\mathrm{a}, \mathrm{b}, \mathrm{c}}$ & $25.72^{\mathrm{a}, \mathrm{d}}$ & $14.34^{\mathrm{a}, \mathrm{c}, \mathrm{e}}$ \\
\hline & & $(20.68)$ & $(23.14)$ & $(12.90)$ \\
\hline & \multirow[t]{2}{*}{$\mathrm{NC}$} & $77.15^{\mathrm{IV}}$ & $16.86^{\mathrm{II}, \mathrm{VII}}$ & $17.63^{\mathrm{II}, \mathrm{VII}}$ \\
\hline & & $64.65)$ & (10.44) & (9.66) \\
\hline & \multirow[t]{2}{*}{ Total } & $109.02^{2,4,5}$ & $42.58^{2,3,6}$ & $31.97^{3,7}$ \\
\hline & & (78.27) & $(28.64)$ & $(20.81)$ \\
\hline & $\mathrm{C} / \mathrm{T}$ & 0.29 & 0.60 & 0.45 \\
\hline \multirow{7}{*}{ Autumn } & \multirow[t]{2}{*}{$\mathrm{CO}$} & $71.97^{\mathrm{c}}$ & $33.81^{\mathrm{d}}$ & $7.06^{\mathrm{e}}$ \\
\hline & & $(15.00)$ & $(21.11)$ & $(2.41)$ \\
\hline & \multirow[t]{2}{*}{$\mathrm{NC}$} & $78.32^{\mathrm{v}}$ & $9.52^{\mathrm{II}, \mathrm{VI}, \mathrm{VII}}$ & $10.80^{\mathrm{II}, \mathrm{VIII}}$ \\
\hline & & $(46.36)$ & $(4.31)$ & $(4.82)$ \\
\hline & \multirow[t]{2}{*}{ Total } & $150.29^{5}$ & $43.33^{6}$ & $17.86^{7}$ \\
\hline & & $(61.36)$ & $(22.12)$ & $(5.70)$ \\
\hline & $\mathrm{C} / \mathrm{T}$ & 0.48 & 0.78 & 0.40 \\
\hline
\end{tabular}

commercial part of the catch, which ranged from 72 $\mathrm{kg} / \mathrm{hr}$ to $5 \mathrm{~kg} / \mathrm{hr}$, even though the bathymetric differences during summer were not statistically significant.

The commercial/total $(\mathrm{C} / \mathrm{T})$ ratio by weight of the whole catch attained the highest values in the stratum 500-700 $\mathrm{m}(0.60-0.78)$. In the other zones, it was generally lower than 0.50 , and it ranged from 0.29 to 0.48 in the zone $300-500 \mathrm{~m}$ and from 0.35 to 0.45 in the zone $700-900 \mathrm{~m}$.

\section{a) Fish}

The CPUE of fish ranged from $11.5 \mathrm{~kg} / \mathrm{hr}(700-$ $900 \mathrm{~m}$, spring) to $133 \mathrm{~kg} / \mathrm{hr}$ (300-500 m, autumn), and its variation with depth and season followed the same pattern with that of the total CPUE (Fig. 3).

In the shallower zone, the ratio $\mathrm{C} / \mathrm{T}$ for fish was generally low (0.25-0.44), and the commercial part of the fish catch showed a CPUE ranging from $23 \mathrm{~kg}$ / hr (spring) to $59 \mathrm{~kg} / \mathrm{hr}$ (autumn). A total of 60 fish species were caught in this zone. The most important of these, caught constantly in high quantities was Chlorophthalmus agassizii (25.5-47.7 kg/hr) (Table 2). Another important species was Squalus blainvillei (3-10.3 kg/hr). Merluccius merluccius and Galeus melastomus were constantly present in the shallowest depth zone with CPUE ranging from $1.5 \mathrm{~kg} / \mathrm{hr}$ (spring) to $9.2 \mathrm{~kg} / \mathrm{hr}$ (autumn) and from $1.4 \mathrm{~kg} / \mathrm{hr}$ (spring) to $4.1 \mathrm{~kg} / \mathrm{hr}$ (autumn), respectively. Gadiculus argenteus and Scyliorhinus canicula were also found constantly in this stratum with a peak of $12.4 \mathrm{~kg} / \mathrm{hr}$ and $6 \mathrm{~kg} / \mathrm{hr}$, respectively, in autumn. The CPUE of Argentina sphyraena was also important (2.6-5.8 kg/ h). Micromesistius poutassou showed a high CPUE in autumn $(17.3 \mathrm{~kg} / \mathrm{hr})$. Finally, the CPUE of Lepidorhombus boscii ranged from $2 \mathrm{~kg} / \mathrm{hr}$ (spring) to $6.8 \mathrm{~kg} / \mathrm{hr}$ (autumn).

The stratum 500-700 m showed the highest $\mathrm{C} / \mathrm{T}$ ratios for fish (0.49-0.73), and the CPUE of commer- 


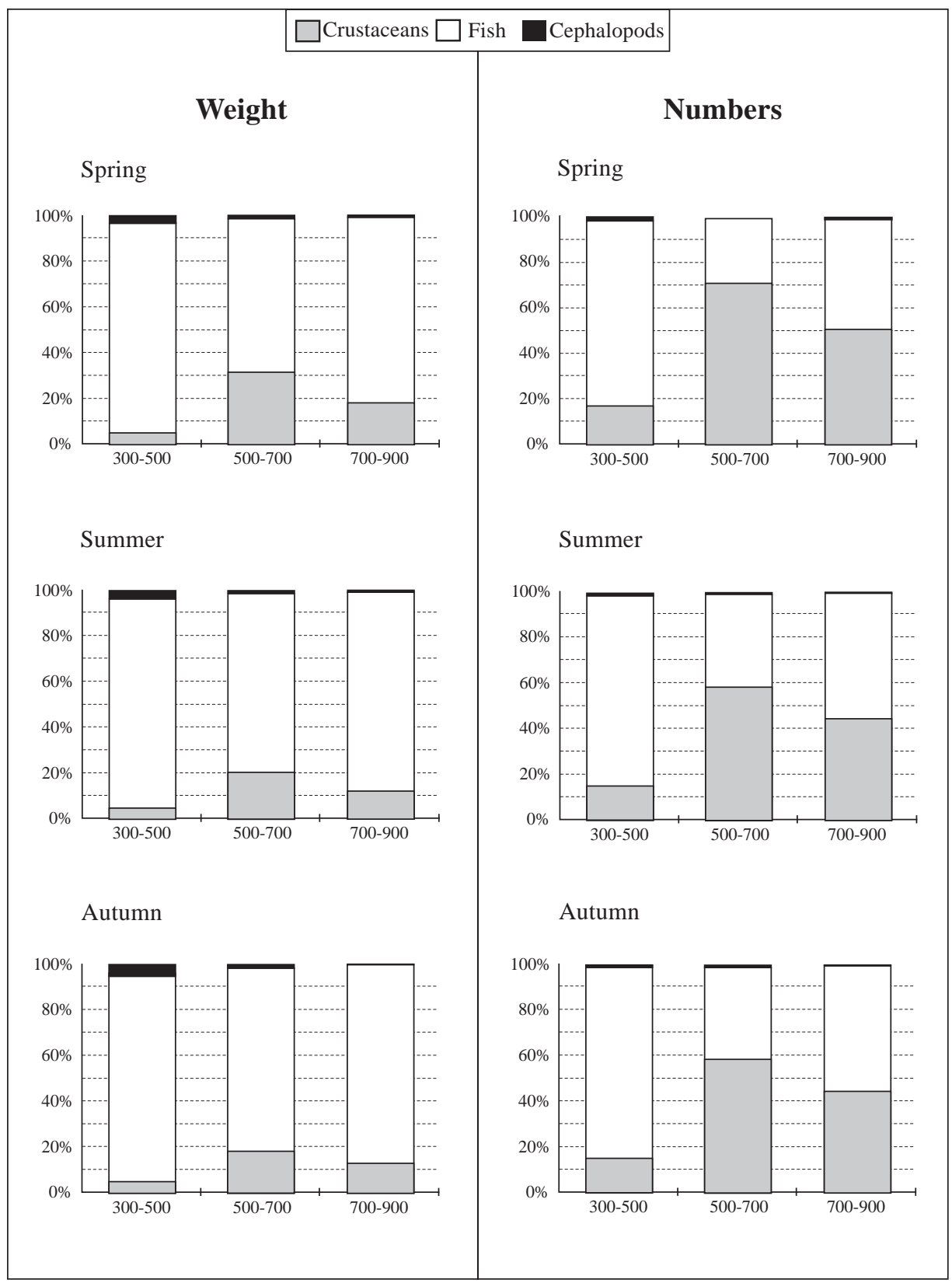

Fig. 2. Catch composition as proportion (\%) by weight $(\mathrm{kg} / \mathrm{hr})$ and by number $(\mathrm{N} / \mathrm{hr})$ per depth stratum and season.

cial fish ranged from $7 \mathrm{~kg} / \mathrm{hr}$ (spring) to $25 \mathrm{~kg} / \mathrm{hr}$ (autumn). The most important of the 43 fish species of this zone were Helicolenus dactylopterus with CPUE ranging from $4.1 \mathrm{~kg} / \mathrm{hr}$ (spring) to $7.9 \mathrm{~kg} / \mathrm{hr}$ (summer) and G. melastomus with CPUE ranging from 2.9 $\mathrm{kg} / \mathrm{hr}$ (spring) to $5.7 \mathrm{~kg} / \mathrm{hr}$ (summer). Hoplostethus mediterraneus and C. agassizii were also found constantly with CPUE ranging from 1 to $3.7 \mathrm{~kg} / \mathrm{hr}$ and from 1.1 to $3.9 \mathrm{~kg} / \mathrm{hr}$, respectively. Phycis blennoides was found in this zone with CPUE ranging between $0.6 \mathrm{~kg} / \mathrm{hr}$ and $2.2 \mathrm{~kg} / \mathrm{hr}$. Other notable species included Lophius piscatorius found in summer and autumn (3.4-3.6 kg/hr), S. blainvillei with maximum CPUE during autumn $(5 \mathrm{~kg} / \mathrm{hr})$ and $M$. merluccius with maximum CPUE also in autumn $(2 \mathrm{~kg} / \mathrm{hr})$.

In the zone $700-900 \mathrm{~m}$, the $\mathrm{C} / \mathrm{T}$ ratio of fish was low (0.21-0.37) with the CPUE of the commercial 


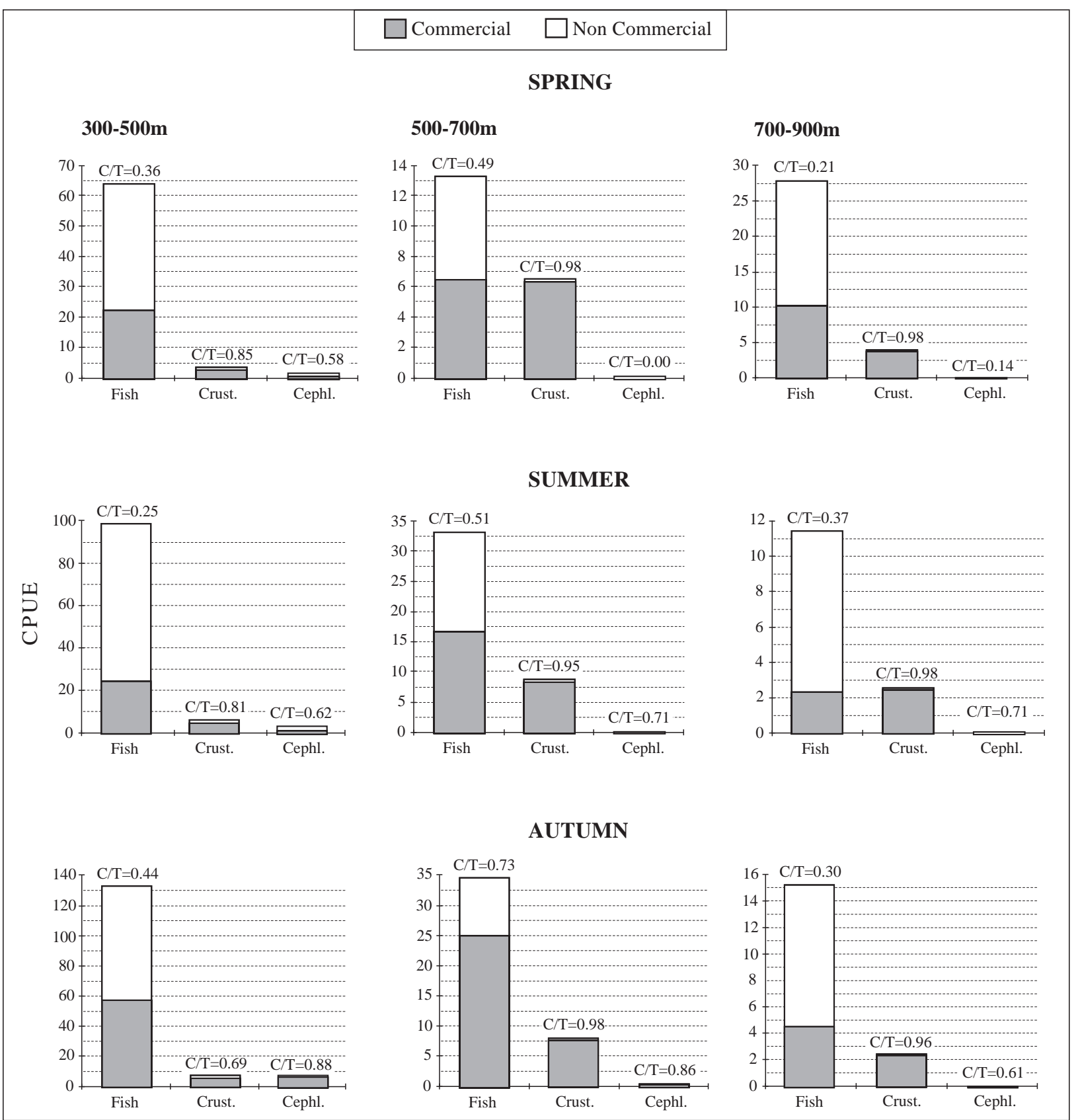

Fig. 3. CPUE $(\mathrm{kg} / \mathrm{hr})$ of the total, commercial and non-commercial fish, crustacean and cephalopod catch per depth zone and season. The ratio of the commercial to the total catch $(\mathrm{C} / \mathrm{T})$ is also presented.

part ranging from $2 \mathrm{~kg} / \mathrm{hr}$ (spring) to $10 \mathrm{~kg} / \mathrm{hr}$ (summer). A total of 37 fish species were found in this depth zone. G. melastomus was dominant $(4.4-8.7 \mathrm{~kg} /$ hr) with Mora moro $(1.4-3 \mathrm{~kg} / \mathrm{hr})$ and $H$. dactylopterus (1.4-2.5 kg/hr) following. H. mediterraneus was caught in lower quantities $(0.8-1.8 \mathrm{~kg} / \mathrm{hr})$, whereas L. piscatorius and L. budegassa were found in relatively high quantities in summer (4.3 and 1.8 $\mathrm{kg} / \mathrm{hr}$, respectively).

\section{b) Crustaceans}

The CPUE of crustaceans ranged from $2.5 \mathrm{~kg} / \mathrm{hr}$ (700-900 m, autumn) to $9.5 \mathrm{~kg} / \mathrm{hr}(300-500 \mathrm{~m}$, autumn) (Fig. 3). It took its highest values in the 
middle stratum (spring, summer) or the first stratum (autumn) and the lowest ones in the deepest stratum during all seasons. The $\mathrm{C} / \mathrm{T}$ ratio was always high (0.69-0.98).

In the shallower stratum, the $\mathrm{C} / \mathrm{T}$ ratio of crustaceans showed lower values (0.69-0.85) compared to the deeper zones, and the CPUE of the commercial catch ranged from $3 \mathrm{~kg} / \mathrm{hr}$ (spring) to $6.5 \mathrm{~kg} / \mathrm{hr}$ (autumn). A total of 16 crustacean species were found in this depth zone, and Parapenaeus longirostris was the dominant species during all seasons $(2.4-6.1 \mathrm{~kg}$ / hr). Plesionika heterocarpus also had a constant presence in the catch of this depth zone with a CPUE of $2.8 \mathrm{~kg} / \mathrm{hr}$ in autumn.

The middle zone displayed the maximum CPUE of commercial crustaceans $(6-8.5 \mathrm{~kg} / \mathrm{hr})$ with $\mathrm{C} / \mathrm{T}$ always higher than 0.9 . From the 15 species caught, Aristaeomorpha foliacea $(4.3-5.8 \mathrm{~kg} / \mathrm{hr}$ ) followed by Plesionika martia $(1.3-1.8 \mathrm{~kg} / \mathrm{hr})$ were the most important species. Aristeus antennatus was also found constantly in low quantities $(0.4-0.65 \mathrm{~kg} / \mathrm{hr})$.

In the deeper zone, a decrease in the catch of crustaceans was observed and although the $\mathrm{C} / \mathrm{T}$ ratio remained high $(>0.95)$, the CPUE of the commercial part ranged between 2 and $4 \mathrm{~kg} / \mathrm{h}$. From the 11 species found in that zone, A. foliacea $(1.2-2.8 \mathrm{~kg} / \mathrm{hr})$ was the main species caught with $A$. antennatus (0.3$1.1 \mathrm{~kg} / \mathrm{hr}$ ) ranking second.

\section{c) Cephalopods}

The total CPUE of cephalopods ranged from 0.03 $\mathrm{kg} / \mathrm{hr}(700-900 \mathrm{~m}$, autumn) to $7.7 \mathrm{~kg} / \mathrm{hr}(300-500$ $\mathrm{m}$, autumn) and it showed an important decrease with depth during all the surveys (Fig. 3).

In the first stratum, the $\mathrm{C} / \mathrm{T}$ ratio was high (0.580.88 ) and the commercial cephalopod catch had a CPUE range from $1 \mathrm{~kg} / \mathrm{hr}$ (spring) to $7 \mathrm{~kg} / \mathrm{hr}$ (autumn). A total of 16 cephalopod species were caught in this zone. From these, Loligo forbesi was the most important species found during all seasons with CPUE ranging from $0.5 \mathrm{~kg} / \mathrm{hr}$ (spring) to $2.1 \mathrm{~kg} / \mathrm{hr}$ (autumn). Todarodes sagittatus was found in relatively high quantities in autumn $(3.3 \mathrm{~kg} / \mathrm{hr})$. Illex coindetii was also important in autumn $(1.1 \mathrm{~kg} / \mathrm{hr})$. Finally, Pteroctopus tetracirrhus was present in low quantities $(<1 \mathrm{~kg} / \mathrm{hr})$ in all surveys, but during autumn its CPUE was negligible.

In the second stratum, the CPUE of cephalopods ranged from to $0.2 \mathrm{~kg} / \mathrm{hr}$ (spring) to $0.6 \mathrm{~kg} / \mathrm{hr}$ (au- tumn). From the 7 species caught, the most notable species was Todarodes sagittatus, which contributed in the catch in autumn and summer with low CPUE $(<1 \mathrm{~kg} / \mathrm{hr})$.

In the third stratum, the CPUE of cephalopods was always lower than $0.1 \mathrm{~kg} / \mathrm{h} .5$ species were found in that depth stratum.

\section{Discussion}

The prevailing role of depth, with a secondary seasonal influence, on the demersal fish and megafaunal changes in the Greek waters and more generally in the Mediterranean has already been documented by different authors (Abelló et al., 1988; Cartes and Sardà, 1992, 1993; Cartes, 1993; Cartes et al., 1994; D'Onghia et al., 1998, Stefanescu et al., 1994; Ungaro et al., 1999; Kallianiotis et al., 2000; Labropoulou and Papaconstantinou, 2000a). Our results showed a general pattern where fish were highly dominant (in number and weight) in depths 300$500 \mathrm{~m}$ with crustaceans and cephalopods ranking second and third, respectively, independent of season. The importance of crustaceans increased in increasing depths (500-900 m) and mainly in the zone 500-700 m, although fish remained dominant in terms of weight. On the contrary, the presence of cephalopods was dramatically reduced with depth. A similar trend, where the number of crustaceans increased with depth and molluscs became rare in stations deeper than $200 \mathrm{~m}$, was reported for Greek waters (Cretan Sea) by Smith et al. (1997).

Although the marketable total catch and the commercial catch of fish and cephalopods was higher in the shallower stratum $(300-500 \mathrm{~m})$ during all seasons, the commercial catch of crustaceans was higher in the second stratum (500-700).

The most abundant high value species of the shallower stratum were M. merluccius, P. longirostris, $S$. blainvillei and L. boscii. However, this depth zone was characterized by a particularly high abundance of the non-commercial species $C$. agassizii, as well as of the importance of other non-commercial species such as $G$. argenteus and A. sphyraena. The C/T ratio of this zone was generally low $(<0.5)$, and even though the marketable catch of this zone was higher compared to deeper waters, the discarded part of the catch was even higher. A factor which may reduce the ratio of commercial/non-commercial species is increasing fishing pressure over time (Overholtz and Tyler, 1985). In the Greek Ionian Sea, fishing activity is 
carried out mainly down to $400 \mathrm{~m}$ and most of the stocks were found to be overexploited (Stergiou et al., 1997) down to this depth. Consequently, apart from other factors related to the geomorphology and oceanography of the study area, the commercial fishery may have affected the species composition of the $300-$ $500 \mathrm{~m}$ depth zone.

The two deeper zones can be considered as unexploited and in pristine state, since fishing activities do not reach these depths. The most important species for fisheries found in the middle stratum were H. dactylopterus, red shrimps (mainly A. foliacea), M. merluccius and S. blainvillei. H. dactylopterus, although found in all the depth zones examined, showed its maximum of abundance in the $500-700 \mathrm{~m}$ zone during all seasons. Also A. foliacea, which was caught in the two deeper strata, was more abundant in the middle zone. Despite the decrease of the total catch in this depth zone, it must be noted that the CPUE of non-commercial species was reduced in this depth zone and the $\mathrm{C} / \mathrm{T}$ ratio was generally high. Finally, in the deeper zone, both the catch and the $\mathrm{C} / \mathrm{T}$ ratio were low. However, species of considerable value, such as A. foliacea, A. antennatus, $H$. dactylopterus and Lophius spp., were found in non-negligible quantities.

A seasonal trend in the CPUE was observed in all depths, although not significant in the deepest zone, with a minimum in spring and a maximum in autumn in the shallower or in summer in deeper waters. This phenomenon may be attributed to the yearly recruits and to species movements. However, in the shallower zone, the influence of fishing activities on the seasonal variability of the catches could also be considered. The observed minimum CPUE in spring coincides with the end of the trawl-fishing period, whereas the maximum observed CPUE in the autumn in this stratum coincides with the end of the closed season for trawling ( $1^{\text {st }}$ June to $30^{\text {th }}$ September).

Even though the comparison of species abundance with other Mediterranean studies is difficult, because of the different types of gears and methods used, our results indicate comparable or even higher abundance for some deep-water species of high commercial value. More specifically, in an earlier investigation of the deep waters of the central E. Ionian Sea (Greek waters) the following abundance values were reported for the main species: $0.3-6.4 \mathrm{~kg} / \mathrm{hr}$ for $H$. dactylopterus, $9.1-20.1 \mathrm{~kg} / \mathrm{hr}$ for A. foliacea and $0.5-$ $7.7 \mathrm{~kg} / \mathrm{hr}$ for A. antennatus (Anon., 1999). From experimental trawling carried out in the Western Ionian
Sea (Italian waters), an abundance ranging from 0.3 to $2.3 \mathrm{~kg} / \mathrm{hr}$, depending on the season, was reported for $H$. dactylopterus (D'Onghia et al., 1998). In the same area, the abundance of $A$. foliacea ranged between 0.3 and $1.6 \mathrm{~kg} / \mathrm{hr}$, that of $A$. antennatus between 3.6 and $8.2 \mathrm{~kg} / \mathrm{hr}$ and finally that of Lophius spp. from 1 to $3.3 \mathrm{~kg} / \mathrm{hr}$. For the Western Mediterranean (Catalan Sea) a biomass range of 0.03 to $0.2 \mathrm{~kg} /$ hr (depth zone 552-1 $149 \mathrm{~m}$ ) was referred for $A$. antennatus, whereas $A$. foliacea was absent (Cartes and Sardà, 1992). Concerning the deep-water red shrimps, more information is given in a recent comparative work based on the results of the MEDITS 1994-99 projects, where a common gear and working protocol was used by all the participants. According to this, although an underestimation of deep-water shrimps was observed in the Greek waters for the first years, probably due to the inexperience of Greek fishermen to deep-water fishing, during the last years, remarkably high biomass indices were found mainly for A. foliacea in the Greek waters and the Eastern Ionian Sea (Cau et al., 2002). Particularly in 1999, the biomass index obtained for A. foliacea in the Eastern Ionian Sea was the highest observed for all the Mediterranean areas under study.

In conclusion, the above results show the existence of important fisheries resources in the deep waters of the Greek Ionian Sea. Species such as $A$. foliacea, A. antennatus and $H$. dactylopterus, which are unknown in most Greek fish markets, are extensively exploited in the Western and Central Mediterranean by deep water trawling down to $1000 \mathrm{~m}$ (Ragonese and Reale, 1992; Ragonese et al., 1994; Sardà and Cartes, 1994). The extension of Greek bottom trawling to deeper waters is expected to lead to a reduction in fishing pressure in shallower waters and provide new products to the market. The relatively high proportion of commercial species compared to the discarded part in the deeper waters, zone 500$700 \mathrm{~m}$, encourages their exploitation. Although Greek fishermen are not experienced in deep-water fishing and until recently believed that no marketable resources existed in deeper waters, they showed a high interest to participate in the experimental cruises for training purposes. A few of them have already started an occasional exploitation of red shrimps, which were welcomed in the regional market with relatively low price at the beginning and increasing afterwards. However, a better knowledge of the deep-water species and ecosystem, is required in order to formulate an effective management scheme for deep-water resources and regulate their exploitation in a sustainable way. Deep-water ecosystems are known to be 
particularly fragile mostly inhabited by slow growing, long lived and late maturing species having low fecundity (Koslow et al., 1995; Labropoulou and Papaconstantinou, 2000b; Massutí et al., 2000; Clark, 2001; Morales-Nin, 2001). These characteristics make the deep-water species particularly vulnerable to overexploitation with a slow recovery rate. There are different examples over the world where initially large deep-water stocks decline quite steeply after intensive fisheries exploitation for a few years (Haedrich et al., 2001). A similar case in the Mediterranean may be that of $A$. foliacea. This species relatively abundant in the easternmost Mediterranean is absent or rare in the westernmost Mediterranean, where it was previously fished in high quantities (Orsi Relini and Relini, 1985; Relini and Orsi Relini, 1987; Campillo, 1994). Among other explanations given for its distribution pattern along the Mediterranean, over-fishing is considered a major factor that has depleted its stocks westwards (Orsi Relini and Relini, 1985; Relini and Orsi Relini, 1987; Matarrese et al., 1997). A management measure that could contribute to the avoidance of such phenomena can be the increase of the minimum mesh size for deep-water trawling, taking also into account the tendency of larger individuals to inhabit deeper waters, known as the bigger-deeper phenomenon (MacPherson and Duarte, 1991). The implemented $20 \mathrm{~mm}$ (side) mesh size for the Mediterranean is not selective for important species such as $A$. foliacea, A. antennatus, $P$. longirostris, $M$. merluccius and M. poutassou (Ragonese and Bianchini, 1996; D'Onghia et al., 1998). A mesh size of at least 28-30 $\mathrm{mm}$ is proposed. On the other hand, measures such as closed seasons for trawling may be beneficial for the stocks. In particular, the official closure of the trawl fishery in Greek waters every summer ( $1^{\text {st }}$ June to $30^{\text {th }}$ September) could be beneficial for red shrimps since it coincides with their reproduction period (Anon., 2001; Kapiris and Thessalou-Legaki, 2001).

\section{References}

ABELlÓ, P., F. J. VALLADARES and A. CASTELLON. 1998. Analysis of the structure of decapod crustacean assemblages off the Catalan coast (North-West Mediterranean). Mar. Biol., 98: 39-49.

ANON. 1999. Developing deep water fisheries: data for their assessment and for understanding their interaction with and impact on a fragile environment. EC FAIR project CT 95-0655. Final Report of Partner, No. 6, National Centre for Marine Resources (Greece), p. 1-144.

2001. Exploration of pristine red shrimp resources and comparison with exploited ones in the Ionian Sea (RESHIO). Interim Report, NCMR, $50 \mathrm{p}$.
CAMPILLO, A. 1994. Bio-ecology of Aristeus antennatus in the French Mediterranean. In: Life cycles and fisheries of the deep-water red shrimps Aristaeomorpha foliacea and Aristeus antennatus. M.L. Bianchini and S. Ragonese (eds.). N.T.R.-I.T.P.P. Spec. Publ., 3: 25-26.

CARBONELL, A. 1994. The status of fishery for Aristeus antennatus in Majorca Island waters. In: Life cycles and fisheries of the deep-water red shrimps Aristaeomorpha foliacea and Aristeus antennatus. M. L. Bianchini and S. Ragonese (eds.), N.T.R.-I.T.P.P. Spec. Publ., 3: 1516.

CARTES, J. E. 1993. Deep-sea decapod fauna of the Western Mediterranean: bathymetric distribution and biogeographic aspects. Crustaceana, 65(1): 29-40.

CARTES, J. E., J. B. COMPANY and F. MAYNOU. 1994. Deep-water decapod crustacean communities in the Northwestern Mediterranean: influence of submarine canyons and season. Mar. Biol., 120: 221-229.

CARTES, J. E. and F. SARDÀ.1992. Abundance and diversity of decapod crustaceans in the deep-Catalan Sea (Western Mediterranean). J. Nat. Hist., 26: 1305-1323.

CARTES, J. E. and F. SARDÀ. 1993. Zonation of deep-sea decapod fauna in the Catalan Sea (Western Mediterranean). Mar. Ecol. Prog. Ser., 94: 27-34.

CAU, A., A. CARBONELL, M. C. FOLLESA, A. MANNINI, G. NORRITO, L. ORSI-RELINI, C.-Y. POLITOU, S. RAGONESE and P. RINELLI. 2002. MEDITS-based information on the deep-water red shrimps Aristaeomorpha foliacea and Aristeus antennatus (Crustacea: Decapoda: Aristaeidae). Sci. Mar., 66(Suppl. 2): 103124.

CLARK, M. 2001. Are deepwater fisheries sustainable? - the example of orange roughy (Hoplostethus atlanticus) in New Zealand. Fish. Res., 51(2-3): 123-135.

D'ONGHIA, G., A. TURSI, P. MAIORANO, A. MATARRESE and M. PANZA. 1998. Demersal fish assemblages from the bathyal grounds of the Ionian Sea (middle-eastern Mediterranean). Ital. J. Zool., 65: 287-292.

GORDON, J. 2001. Deep-water fish and fisheries: introduction. Fish. Res., 51(2-3): 105-111.

HAEDRICH, R. L., N. R. MERRETT and N. R. O'DEA. 2001. Can ecological knowledge catch up with deepwater fishing? A North Atlantic perpective. Fish. Res., 51(2-3): 113-122.

KALLIANIOTIS, A., K. SOPHRONIDIS, P. VIDORIS and A. TSELEPIDIS. 2000. Demersal fish and megafaunal assemblages on the Cretan continental shelf and slope (NE Mediterranean): seasonal variation in species density, biomass and diversity. Prog. Oceanogr., 46: 429455.

KAPIRIS, K. and M. THESSALOU-LEGAKI. 2001. Observations on the reproduction of Aristaeomorpha foliacea (Crustacea: Aristaeidae) in the SE Ionian Sea. Rapp. Comm. Int. Mer Médit., 36: 281.

KOSLOW, J. A., J. BELL, P. VIRTUE and D.C. SMITH. 1995. Fecundity and its variability in orange roughy: effects of population density, condition, egg size, and senescence. J. Fish Biol., 47: 1063-1080. 
LABROPOULOU, M. and C. PAPACONSTANTINOU. 2000a. Community structure of deep-sea demersal fish in the North Aegean Sea (northeastern Mediterranean). Hydrobiologia, 440: 281-296.

LABROPOULOU, M. and C. PAPACONSTANTINOU. 2000b. Comparison of otolith growth and somatic growth in two macrourid fishes. Fish. Res., 46: 177-188.

MacPHERSON, E. and C. M. DUARTE. 1991. Bathymetric trends in demersal fish size: is there a general relationship? Mar. Ecol. Progr. Series, 71: 103-112.

MASSUTÍ, E., B. MORALES-NIN and J. MORANTA. 2000. Age and growth of blue-mouth, Helicolenus dactylopterus (Osteichthyes: Scorpaenidae), in the western Mediterranean. Fish. Res., 46: 165-176.

MATARRESE, A., G. D'ONGHIA, A. TURSI and P. MAIORANO. 1997. Vulnerability and resilience of Aristaeomorpha foliacea (Risso, 1827) and Aristeus antennatus (Risso, 1816) (Crustacea, Decapoda) in the Ionian Sea. S. It. E. Atti, 18: 535-538.

MORALES-NIN, B. 2001. Mediterranean deep-water fish age determination and age validation: the state of the art. Fish. Res., 51(2-3): 377-383.

ORSI RELINI, L. and G. RELINI. 1985. The red shrimps fishery in the Ligurian Sea: mismanagement or not? FAO Fish. Rep., 336: 99-106.

OVERHOLTZ, W. J. and A. V. TYLER. 1985. Long-term changes of the demersal fish assemblages of George Bank. Fish. Bull., 83: 507-520.

RAGONESE, S. and B. REALE. 1992. Estimation of mortality rates and critical age of Helicolenus dactylopterus (Pisces: Scorpeniformes) in the Sicilian Channel (Central Mediterranean Sea). Rapp. Comm. Int. Mer Medit., 33: 307.

RAGONESE, S. and M.L. BIANCHINI. 1996. Growth, mortality and yield-per-recruit of the deep-water shrimp Aristeus antennatus (Crustacea-Aristaeidae) of the Strait of Sicily (Mediterranean Sea). Fish. Res., 26: 125137.

RAGONESE, S., M. L. BIANCHINI, L. DI STEFANO, S. CAMPAGNUOLO and F. BERTOLINO. 1994. Aristaeomorpha foliacea in the Sicilian Channel. In: Life cycles and fisheries of the deep-water red shrimps Aristaeomorpha foliace and Aristeus antennatus. M.L. Bianchini and S. Ragonese (eds). N.T.R.-I.T.P.P. Spec. Publ., 3: 45-46.
RELINI, G. and L. ORSI RELINI. 1987. The decline of red shrimps stocks in the gulf of Genoa. Inv. Pesq., 51(Suppl. 1): $245-260$.

RIGHINI, P. and A. ABELLA. 1994. Life cycle of Aristeus antennatus and Aristaeomorpha foliacea in the Northern Tyrrhenian Sea. In: Life cycles and fisheries of the deep-water red shrimps Aristaeomorpha foliacea and Aristeus antennatus. M.L. Bianchini and S. Ragonese (eds). N.T.R.-I.T.P.P. Spec. Publ., 3: 29-30.

SARDÀ, F. and J. E. CARTES. 1994. Status of the qualitative aspects in Aristeus antennatus fisheries in North Western Mediterranean. In: Life cycles and fisheries of the deep-water red shrimps Aristaeomorpha foliacea and Aristeus antennatus. M. L. Bianchini and S. Ragonese (eds.). N.T.R.-I.T.P.P. Spec. Publ., 3: 23-24.

SMITH C. J., K.-N. PAPADOPOULOU, M. LABROPOULOU and A. TSELEPIDES. 1997. Megafaunal communities of the continental shelf and slope of the Cretan Sea. Proc. $5^{\text {th }}$ Hel. Symp. Oceanogr. \& Fish., NCMR Vol. I: $229-232$.

STEFANESCU, C., D. LLORIS and J. RUCABADO. 1992a. Deep-living demersal fishes in the Catalan Sea (western Mediterranean) below a depth of 1000 m. J. Nat. Hist., 26: $197-213$.

STEFANESCU, C., J. RUCABADO and D. LLORIS. 1992b. Depth-size trends in western Mediterranean demersal deep-sea fishes. Mar. Ecol. Prog. Ser, 81: 205-213.

STEFANESCU, C., D. LLORIS and J. RUCABADO. 1993. Deep-sea fish assemblages in the Catalan Sea (western Mediterranean) below a depth of $1000 \mathrm{~m}$. Deep-Sea Res. I, 40: 695-707.

STEFANESCU, C., B. MORALES-NIN and E. MASSUTI. 1994. Fish assemblages on the slope in the Catalan Sea (western Mediterranean): influence of a submarine canyon. J. Mar. Biol. Ass. U.K., 74: 499-512.

STERGIOU, K. I., E. D. CHRISTOU, D. GEORGOPOULOS, A. ZENETOS and C. SOUVERMEZOGLOU. 1997. In: The Hellenic Seas: Physics, Chemistry, Biology and Fisheries. A. D. Ansell, R. N. Gibson and M. Barnes (eds.). Oceanogr. Mar. Biol., Ann. Rev. 1997, 35: 415-538.

UnGARO, N., C. A. MARANO, R. MARSAN, M. MARTINO, M. C. MARZANO, G. STRIPPOLI and A. VLORA. 1999. Analysis of demersal species assemblages from trawl surveys in the South Adriatic Sea. Aquat. Living Resour., 12(3): 177-185. 